\title{
Nature or Nurture? Judicial \\ Lawmaking in the European Court \\ of Justice and the Andean Tribunal \\ of Justice
}

\author{
Karen J. Alter and Laurence R. Helfer
}

\begin{abstract}
Are international courts power-seeking by nature, expanding the reach and scope of international rules and the courts' authority where permissive conditions allow? Or, does expansionist lawmaking require special nurturing? We investigate the relative influences of nature versus nurture by comparing expansionist lawmaking in the European Court of Justice (ECJ) and the Andean Tribunal of Justice (ATJ), the ECJ's jurisdictional cousin and the third most active international court. We argue that international judges are more likely to become expansionist lawmakers where they are supported by substate interlocutors and compliance constituencies, including government officials, advocacy networks, national judges, and administrative agencies. This comparison of two structurally identical international courts calls into question prevailing explanations of ECJ lawmaking, and it suggests that prevailing scholarship puts too much emphasis on the self-interested power-seeking of judges, the importance of institutional design features, and the preferences of governments to explain lawmaking by international courts.
\end{abstract}

One often hears concerns that international judges may run amok, actively expanding international law in ways not explicitly based on state consent. There is a lot more rhetoric than reality to these concerns. In practice, all judges make law. Indeed, a key reason states delegate authority to international adjudicators is because governments know that agreements are incomplete and that legal commitments will need to be interpreted and gaps filled in. ${ }^{1}$ Yet some international courts and tribunals (ICs) do extend international legal rules in ways that constrain national sovereignty beyond what states had intended. For governments and commentators

We are grateful for financial support from the Center for the Americas at Vanderbilt and the Northwestern Dispute Resolution Research Center, which funded research assistance and field research in Quito, Lima, and Bogota. For helpful comments on previous drafts, we thank David Art, David Boyd, Dan Brinks, Darren Hawkins, Tom Ginsburg, Cesare Romano, Osvaldo Saldias, and Alexander Krasteve Panayotov, and the reviewers and editors at $I O$. Thanks also to Gilda Anahi Gutierrez, Elena HerreroBeaumont, Maria Florencia Guerzovich, and Ryan Mellske, who provided superb research assistance.

1. Hawkins et al. 2006, 17. 
concerned with such expansive judicial lawmaking, the European Court of Justice (ECJ) represents the problem in the extreme.

Decades of ECJ rulings transformed the Treaty of Rome into a de facto constitution for the European Community (EC). ${ }^{2}$ The ECJ achieved this remarkable result by expanding the reach and scope of EC law and by enabling litigants to use the European legal system to promote key EC objectives. For example, the ECJ has condemned Germany's exclusion of women from combat-related military roles, Ireland's censoring of a student brochure locating abortion clinics in Britain, and the EU's implementation of a United Nations (UN) program freezing the assets of alleged terrorist supporters. ${ }^{3}$ Proponents of effective international adjudication see the ECJ as an exemplar for other ICs. ${ }^{4}$ Sovereigntists, by contrast, criticize the ECJ as riding roughshod over national autonomy, ${ }^{5}$ suggesting a cautionary lesson in why states should avoid creating independent ICs.

This article reinvestigates the history and early decisions of the ECJ to explore how context shapes international judicial lawmaking. We do so by comparing the ECJ with its largely unknown cousin - the Andean Tribunal of Justice (ATJ). In 1969, five countries in the Andean region of South America imported from Europe the idea of building a common market through supranational institutions-but without an IC. Andean governments later concluded that the absence of a court undermined the uniform interpretation of and compliance with Andean law. ${ }^{6}$ In 1984, they established the ATJ, explicitly modeling its design on the ECJ.

The ATJ is one of ten ECJ copies, and arguably the most successful. ${ }^{7}$ It is the third-most active IC, having issued nearly 2,000 decisions through 2009. The ATJ has fewer rulings than the European Court of Human Rights and the ECJ, but far more than the World Trade Organization (WTO) dispute settlement system, the International Court of Justice, or Latin America's other ICs-the Inter-American Court of Human Rights and the Central American Court of Justice. ${ }^{8}$ The ATJ has also, as we demonstrate elsewhere, influenced both Andean Community law and the behavior of its member states. ${ }^{9}$

2. See Hartley 1996; Stein 1981; and Weiler 1991.

3. Society for the Protection of Unborn Children Ireland v. Grogan, ECJ Case 159/90, [1991] ECR 4685. Tanja Kreil v. Bundesrepublik Deutschland ECJ Case C-285/98, [2000] ECR I-69. Kadi and Al Barakaat International Foundation v. Council, ECJ Joined Cases C-402/05P \& C-415/05P, [2008] CMLR 41 [2008].

4. Helfer and Slaughter 1997.

5. See Denning 1990; Posner and Yoo 2005; and Rasmussen 1986.

6. See García Amador 1978; and Vargas-Hidalgo 1979, 224.

7. Ten ICs copy design features from the ECJ: the Benelux Court, Andean Tribunal of Justice, European Free Trade Area Court, West African Economic and Monetary Union Court, Common Market for East African States Court, Central African Monetary Community Court, East African Community Court, Caribbean Court of Justice, Southern African Development Community Court, and the proposed African Court of Justice and Human Rights. The Benelux Court, created in 1974, is older than the ATJ; the other ICs are more recent creations.

8. Alter 2008, 57-60.

9. Helfer, Alter, and Guerzovich 2009. 
In this article, we focus on the ATJ's strikingly more modest judicial lawmaking as compared to the ECJ. The ATJ has incorporated the key ECJ doctrines of the supremacy and direct effect of community law. But unlike the ECJ, the ATJ overwhelmingly respects the discretion that Andean law leaves to state actors. Even when provided with opportunities to adopt broad interpretations, the ATJ is generally reluctant to expand its authority or the reach of Andean rules in ways that constrain national sovereignty.

The ECJ/ATJ's comparison reminds one of the "nature" versus "nurture" debate in child rearing. Is it the genes or the environment that shapes how an actor develops? Most international relations and international law scholars favor the nature side of this debate. They assume that judges are "hardwired" to increase their power. It is only limited opportunities or the fear of being sanctioned that inhibits judges' natural tendency to expand their authority. By contrast, nurture-based explanations assume that ICs typically apply the law in fairly straightforward and circumscribed ways. Expansionist lawmaking — which we define as broadening the reach or scope of international law and of IC authority at the expense of national political discretion-requires, according to this view, special nurturing and encouragement.

We investigate the relative influences of nature versus nurture by comparing the first twenty-five years of ATJ and ECJ decision making, periods when the regional organizations that created both courts had smaller memberships, ${ }^{10}$ nascent supranational institutions, and lower trade volumes. We show that the ATJ has generally refrained from the sort of expansionist lawmaking that is the hallmark of its European cousin, and we offer a new explanation of the ECJ's extraordinary lawmaking.

Our analysis has three wider implications. First, we call into question the notion that international judges are power-seeking by nature. This assumption lies at the heart of international relations theories that focus on how specific design features of ICs facilitate or hinder expansionist IC lawmaking. Our analysis of two identically designed ICs suggests that scholars have placed too much emphasis on formal institutional rules and state control of judges.

Second, we argue that ICs are more likely to be expansionist where substate and societal interlocutors-government officials, national judiciaries, advocacy networks, administrative agencies, or the public more generally-encourage IC lawmaking and facilitate compliance with IC rulings. In emphasizing the preferences of these actors, we implicitly reject the dominant international relations approach that views the preferences of states as the primary factor shaping IC decision making.

A third broad policy implication of our analysis is that politically independent ICs can, contrary to sovereigntists' fears, be active but not activist, interpreting

10. The European Community grew from six members in 1958 (France, Germany, Italy, Luxembourg, the Netherlands, and Belgium) to nine in 1973 (when the United Kingdom, Ireland, and Denmark joined) to ten members in 1981 (when Greece joined). Spain and Portugal joined the EC in 1985. For most of the ATJ period we study, the Andean Community had five members. The original Andean Pact included Bolivia, Chile, Colombia, Ecuador, and Peru. Chile withdrew in 1976. Venezuela joined in 1973 and withdrew in 2006. 
and completing international contracts while avoiding expansive judicial lawmaking that compromises state sovereignty.

In the next section, we define expansionist international judicial lawmaking and situate our analysis in existing scholarship on ICs. We show that the ECJ and ATJ are nearly identically designed institutions, creating a natural experiment to test nature versus nurture theories of judicial lawmaking. In the second section, we document the key trends in ATJ decision making. We show that Andean judges have copied several key ECJ doctrines. But we also show that Andean judges are, unlike their European counterparts, generally deferential to governments with the exception of the domain of intellectual property law-a puzzle we explain in the third section by comparing how different environmental factors have influenced ATJ and ECJ lawmaking. In the final section, we analyze the implications of this comparison for understanding how environmental and political context shapes IC lawmaking. Inasmuch as our data on the ATJ is new and largely unknown, the appendix explains our methodological choices and provides a guide for future research.

\section{Theories of Expansionist Judicial Lawmaking by International Courts}

Judging often involves lawmaking. ${ }^{11}$ When faced with controversies involving indeterminate rules, judges must interpret those rules to resolve the parties' disputes. Most IC lawmaking fills gaps in existing legal rules, or, in the terminology of rational choice, completes incomplete contracts. Our focus, however, is on expansionist international judicial lawmaking, which we define as occurring when ICs identify new legal obligations or constraints not found in treaty texts or supported by the intentions of their drafters, and when these obligations or constraints narrow states' discretion. Typically, expansionist lawmaking significantly broadens the substantive reach of international law and asserts the IC's authority to interpret that law. ${ }^{12}$ We do not include in this definition a requirement that international judges rule against governments. ICs can expand international law without ruling against governments; conversely, they can rule against governments without expanding international law.

Most international relations theories begin from the premise that judges are power-seeking by nature, using empowerment to explain why ICs expand judicial authority at the expense of state discretion. This assumption also underpins most claims about how institutional design features contribute to expansionist lawmaking.

There are two variants of this expansionist-by-nature theory. One set of scholars focus on how IC access rules shape opportunities to litigate, and thereby oppor-

11. Shapiro $1981,29$.

12. This definition differs slightly from Steinberg, who focuses on the lawmaking by the Appellate Body and dispute settlement panels of the World Trade Organization (WTO). Steinberg, 2004, 250-57. 
tunities for expansionist lawmaking. Posner and Yoo claim that where states must consent to submit disputes to international adjudication, ICs will strive to make their rulings politically palatable to governments. By contrast, courts that do not require state consent to hear a particular dispute (ICs with compulsory jurisdiction) and those that allow private parties to initiate litigation are more independent and therefore more likely to issue expansionist rulings that displease states. ${ }^{13}$ Other scholars concur that compulsory jurisdiction and private access lead to more active and independent courts that are more likely to expand the reach and scope of international law. ${ }^{14}$ For example, Keohane, Moravcsik, and Slaughter argue that "transnational dispute resolution seems to have an inherently more expansionary character"; noting that "a steady flow of cases ... allows a court to become an actor on the legal and political stage" and that "a court gains political capital from a growing caseload by demonstrably performing a needed function." 15

A second set of scholars focus on the tools states use to thwart expansionist lawmaking. Building on the insights of principal-agent theory, these scholars argue that ICs are less expansionist where states can easily revise international rules, where judicial terms are short or subject to reappointment, and where design features allow states to punish judges for decisions they dislike. ${ }^{16}$ Ginsburg adds that judicial lawmaking should increase with the number of parties to an agreement and the difficulty of amending the treaty or overruling judges, and decrease with the ease of exit from the regime. ${ }^{17}$

The ECJ-ATJ comparison presents us with a natural experiment that holds constant these design features to explore how environmental factors and political context shapes judicial behavior. Andean governments replicated the ECJ's design, hoping to copy its success in enhancing respect for common market rules. ${ }^{18}$ The ATJ's architects were well aware of the ECJ's history of expansionist lawmaking. Although neither the Cartagena Agreement nor the Treaty Establishing the Andean Tribunal explicitly stated that Andean law has direct effect in national legal systems or that it is supreme to national law, negotiators assumed that the Andean system would replicate these judge-made EC doctrines. ${ }^{19}$ But the drafters also sought to hem in expansionist lawmaking by allowing only member states to bring noncompliance complaints, and by explicitly stating that the ATJ should not delve into the facts of preliminary rulings. The ATJ's faithful respect of these limitations contributed to the dearth of Andean cases in its early years. In 1996, member states

13. Posner and Yoo, 2005, 6-7.

14. See Hawkins and Jacoby 2008; Helfer and Slaughter 1997; Keohane, Moravcsik, and Slaughter 2000 .

15. Keohane, Moravcsik, and Slaughter 2000, 459, 482.

16. See Stephan 2002; Tsebelis and Garrett 2001; and Vaubel 2006.

17. Ginsburg 2005. Steinberg offers a more nuanced version of this argument, suggesting that the WTO Appellate Body considers how its rulings will affect the attitudes of WTO member states. Steinberg 2004.

18. Keener 1987, 49.

19. See note 35 . 
relaxed both of these restrictions, so that after 1996, the ATJ resembles the ECJ's structure even more closely. ${ }^{20}$

Both the ECJ and the ATJ provide the same mechanisms for challenging government behavior that conflicts with community rules. Both systems contain a noncompliance procedure that enables private actors and member states to inform the community secretariats about rule violations. The secretariats investigate the alleged violation, and, if necessary, file noncompliance complaints with the ECJ/ATJ. Both systems also contain a preliminary ruling mechanism in which private actors invoke community law in domestic litigation and national judges refer questions of interpretation to the ECJ/ATJ. Domestic courts then apply the ECJ/ATJ ruling to the case at hand. In both systems, sanctions can be imposed if a state fails to comply with the court's ruling. ${ }^{21}$ As of 1996, the Andean system has one feature the ECJ lacks. If the Secretariat refuses to raise a noncompliance suit, a private actor can bring the suit directly to the ATJ.

Although the Andean Pact and the EC initially had different substantive goals, ${ }^{22}$ the Andean Pact's Cartagena Agreement contained the same key elements of the Treaty of Rome that the ECJ used to expand its authority. Both treaties prohibit member states from creating new barriers to trade, require national treatment for products from other member states, and allow supranational bodies to adopt directly applicable secondary legislation. ${ }^{23}$

Both regional systems also provide governments with the same formal opportunities to sanction expansionist lawmaking: judges are appointed to fixed, renewable terms $;{ }^{24}$ member states can redefine each court's jurisdiction by unanimously

20. Article 25 of the revised ATJ Treaty allows private actors to request the General Secretariat (which replaced the Junta) to investigate noncompliance and to raise noncompliance cases directly with the ATJ. The revised Article 34 allows the ATJ to consider the facts of preliminary references "when essential for the requested interpretation." A new section IV authorizes private actors to bring to the ATJ cases where the General Secretariat failed to act. A new Article 31 allows private actors to complain to national courts if member countries fail to make the changes necessary to comply with Andean law. The latter provision, however, required domestic implementation, which apparently never occurred. These changes are revealed by comparing the original Treaty Creating the Court of Justice of the Cartagena Agreement (18 Int'l Legal Materials 1203 (1979)) to the treaty as amended by the Protocol of Cochabamba (28 May 1996). Available at 〈http://www.comunidadandina.org/ingles/ normativa/ande_trie $2 . h t m\rangle$. Accessed 22 June 2010. For more on the evolution of the Andean legal system, see Helfer and Alter 2009, 879-83.

21. The Andean legal system has always allowed for retaliatory sanctions (Article 25 of the original ATJ treaty; Articles 27 and 30 of the revised treaty). In 1989-after the period of time we study-the EC added a system of fines for noncompliance with ECJ rulings. See Tallberg 2003, 73-84.

22. The Andean Pact was focused on generating import-substitution capabilities by building regional industrial programs. With this goal in mind, the Pact's secondary legislation controversially regulated foreign investment and the transfer of intellectual property and technical knowledge to Andean countries.

23. In the Andes, changing secondary legislation requires the support of all member states; in Europe, unanimity was required during the period we investigate. As of 1989, some secondary European legislation can be changed by a qualified majority vote.

24. Andean judges serve six-year terms, as do their European equivalents. Whereas ECJ judges can be reappointed numerous times, ATJ judges can only be reappointed once. Judges on both courts can only be removed for serious misconduct. No effort has been made to remove an ATJ or an ECJ judge. For more, see note 79 . 
amending its founding charter; ${ }^{25}$ and they may in theory withdraw from both the EC and Andean Community. ${ }^{26}$ As a practical matter, exit is unlikely in Europe, whereas states have exited from the Andean regime (for reasons unrelated to the ATJ). ${ }^{27}$

Notwithstanding these nearly identical design features, the next section will show that the ATJ, unlike the ECJ, has not become an expansionist lawmaker.

\section{Does Active Mean Activist? ECJ and ATJ Lawmaking Compared}

This section compares ATJ and ECJ lawmaking over different twenty-five-year periods when each IC was establishing its legal and political authority. Both courts were similarly active during these periods, with a steadily increasing diet of preliminary references. Between 1960 and 1985, the ECJ issued 305 noncompliance decisions and 1,808 preliminary rulings (an average of 86.1 cases per year), whereas the ATJ, with a geographically and demographically smaller region to oversee, issued 85 noncompliance decisions and 1,338 preliminary rulings between 1984 and 2007 (an average of 71.5 per year). ${ }^{28}$ Notwithstanding the large number of cases, European and Andean governments were only weakly committed to economic and legal integration during these periods. Pro-integration litigants urged the courts to overcome these political impediments with teleological interpretations that furthered the treaties' integrationist goals. The ECJ responded eagerly to these entreaties by engaging in expansionist lawmaking, whereas the ATJ was more circumspect.

We give greater attention to the ATJ, an IC whose activities have generated surprisingly little scholarship. We coded all 1,338 ATJ preliminary rulings available on the Andean Community Web site from the tribunal's founding through 2007. Where the ATJ broke new legal ground, we analyzed its decisions in depth. We focused on preliminary rulings because most ECJ lawmaking occurred in such rulings. We also expected ATJ lawmaking to occur in preliminary rulings. The General Secretariat raises most noncompliance cases, and we expected the Secretariat to be sensitive to state concerns and to allege noncompliance only where violations were manifest. However, our review of important preliminary rulings led us to a number of noncompliance decisions, several of which we analyze below.

25. For the ECJ, states amend the Consolidated Treaty on a European Union. For the ATJ, states amend the Treaty Creating the Court of Justice of the Cartagena Agreement. Both treaties have been amended, but only to expand, not limit, each court's jurisdiction. On changes to the ATJ's jurisdiction, see note 20 .

26. Hartley 1999, 164-65.

27. Chile withdrew from the organization in 1976 after a coup by Augusto Pinochet. In 2006, President Hugo Chavez withdrew Venezuela from the Andean Community. In that same year, Chile rejoined the organization as an associate member.

28. ECJ data from Stone Sweet 2004, 72-79. For ATJ litigation patterns, see Helfer and Alter 2009. 
We also conducted more than forty interviews with lawyers, judges, and government officials in Peru, Ecuador, and Colombia.

Our account of ECJ lawmaking relies heavily on Weiler's seminal legal analysis, and on Burley and Mattli's political analysis, both of which argue that legal actors are power-seeking by nature. ${ }^{29}$ Following Weiler, we group our study into time periods that correspond to varying levels of support for regional integration to capture dynamics between political and legal integration.

\section{The Foundational Period: The ATJ During the Andean Pact (1984-95)}

ECJ lawmaking was most expansive during what Weiler labels as the court's "foundational period" from 1962 to the mid-1970s. There was significant political turmoil in Europe during these years. Consumed by internal problems and divergent objectives, European governments seemingly turned away from supranationalism and the goal of building a common market. ${ }^{30}$ Weiler argues that the ECJ responded to this political impasse by being remarkably activist, building through law what supporters of integration could not achieve through politics. In this period, the ECJ established the core doctrines of regional integration - the direct effect, supremacy, and pre-emption of community law over national law, and the implied powers of supranational institutions. ${ }^{31}$

The ATJ's genesis shares some elements of the ECJ's experience, but not others. As in Europe, early on a handful of motivated litigants turned to the court to promote the objectives inscribed in the Cartagena Agreement. ${ }^{32}$ The ATJ responded by mimicking the ECJ. Even though the ATJ's first case did not involve an actual or potential conflict between Andean and national law, the tribunal used its first preliminary ruling to declare the supremacy and pre-emptive power of Andean law (the direct effect of Andean law was assumed). It cited the ECJ's Costa v. Enel decision establishing the supremacy of European law and its Simmenthal ruling that obligated national courts to enforce the primacy of community law. ${ }^{33}$ But whereas the ECJ had framed its analysis in constitutional terms, boldly asserting

29. See Burley and Mattli 1993; and Weiler 1991, 2426. Burley and Mattli (1993, 63) cite Weiler as evidence for their empowerment thesis, and add that self-interested empowerment explains scholarly and national judicial support for ECJ expansionist lawmaking (ibid., 64-65).

30. Hoffmann 1966, 881-95.

31. Weiler 1991, 2445-50.

32. The first ATJ case was raised by Germán Cavelier, who had served as Secretary General of Colombia's Ministry of Foreign Affairs in 1968 and 1969 when the Andean Pact was negotiated. According to attorneys in Cavelier's law firm, Cavelier viewed Andean integration and the ATJ as mechanisms to strengthen international law. Interview by authors with German Marin and Emilio Ferraro, Cavelier Abogados, 11 September 2007, Bogota, Colombia.

33. See ATJ ruling 1-IP-87 (points 2 and 3.5). See the research note for an explanation of the reference system for ATJ rulings. Costa v. Ente Nazionale per L'Energia Elettrica (ENEL), ECJ Case 6/64, [1964] ECR 585, [1964] CMLR 425; Amministrazione delle Finanze dello Stato v. Simmenthal SpA (II), ECJ Case 106/77, [1978] ECR 629, [1978] CMLR 263. 
that "the Community constitutes a new legal order of international law for the benefit of which the states have limited their sovereign rights," ${ }^{34}$ the ATJ stressed the functional necessity and implicit state support for supremacy. ${ }^{35}$

The ATJ's second preliminary ruling raised the question of what becomes of a national law that conflicts with Andean rules yet remains on the books. In the Simmenthal case, the ECJ had resolved this conflict with an unyielding rule: "Every national court must ... apply Community law in its entirety and ... must accordingly set aside any provision of national law which may conflict with it, whether prior or subsequent to the Community rule." 36 The ATJ, although citing the Simmenthal decision, ultimately interpreted Andean law more modestly as "firstly set$\operatorname{tl}[$ ing] for [a rule of] preferential application." National law remains valid and on the books but is not applied. If the conflicting Andean law is later modified, however, the latent national law becomes compatible with community law. ${ }^{37}$

A comparison of the two courts' pre-emption doctrines provides another example of the ATJ's greater deference to state autonomy. Without any textual support in the Treaty of Rome, the ECJ asserted that in fields such as the common commercial policy, Community powers were exclusive and precluded member states from legislating regardless of whether their actions conflicted with community law. In other areas regulated by European law, the ECJ concluded that member states could not legislate even where there is no EC rule on point. Not only do these rulings diminish state discretion, it is the ECJ that determines whether a particular EC rule or policy space is exclusive and pre-eminent. ${ }^{38}$

In striking contrast, the pre-emptive force of Andean law is far more modest. In an early ruling, the ATJ announced the principle of complemento indispensable: even in areas where Andean law clearly governs, member states may enact domestic laws necessary to implement a community rule provided that the laws do not obstruct or nullify that rule. ${ }^{39}$ Stated differently, whereas the ECJ both implied powers not explicitly delegated to the EC and asserted pre-emptive authority even where EC law was silent, the ATJ has not implied powers for the Andean Community, and it has allowed states to retain the power to legislate with the sole exception of national laws that directly conflict with extant community rules.

In a 1990 decision, the ATJ further cabined the pre-emption doctrine. Although citing ECJ case law to reaffirm that Andean laws can displace national rules, the

34. This famous quote is from the Van Gend en Loos decision, ECJ Case 26/62, [1963] ECR 1, 12. Commentators have stressed that the ECJ's constitutional framing was an important political move. See Maduro 1998, 8; Vauchez 2007; and Weiler 1991, 2413-15.

35. The court stated that supremacy "is the essential characteristic of Community Law and a basic requirement for building integration." The ATJ cited a 1980 declaration in which member states had agreed that "the legal system of the [Cartagena] Agreement prevails within the framework of its competences over national norms." ATJ ruling 1-IP-87, point 2.

36. Amministrazione delle Finanze dello Stato v. Simmentha, n. 33, quoted in CMLR, 283.

37. ATJ ruling 2-IP-88, point 2.

38. On the ECJ's doctrine of implied powers, see Weiler 1991, 2415-17.

39. ATJ ruling 2-IP-88, point 3. 
ATJ also stressed that integration is a gradual, incremental process that limits the extent to which Andean rules pre-empt national authority: "Especially, when dealing with complex and vast issues, such as intellectual property, ... it seems logical that many of these diverse issues, even if they have to be a matter of common regulation in the beginning, are still within the competence of the national legislator for an indefinite time until they are effectively covered by the community norms." ${ }^{40}$

Other ATJ rulings during the foundational period exhibited even greater deference. Consider, for example, the multiyear Reynolds Aluminum dispute. The ATJ first rejected the case in 1987 because private actors at the time lacked standing to raise noncompliance suits. ${ }^{41}$ The case reappeared in 1990 as a preliminary ruling with facts strikingly similar to the ECJ's landmark Van Gend en Loos decision of 1962. As in Van Gend en Loos, the plaintiff claimed that the common market treaty created an immediate bar to increasing tariffs on imports from other member states. However, Andean governments had previously adopted, via secondary legislation, a Free Trade Program that allowed broad exemptions from regional free trade rules. The plaintiff nevertheless argued that the Cartagena Agreement should be read as freezing existing tariffs for products exempted by the Program. Colombia countered that the Free Trade Program should be interpreted as effectively amending the treaty. ${ }^{42}$ The ATJ sided with the government, ruling that member states had free reign with respect to products included on the Free Trade Program's list of exceptions. ${ }^{43}$ The ECJ's Van Gend en Loos ruling made the Treaty of Rome a constitutional document that created immediately enforceable rights for private actors and higher-order legal obligations for governments. By contrast, the ATJ in effect interpreted the Cartagena Agreement not as a fixed constitutional charter but only as a starting point for integration, one that member states could amend fairly easily. ${ }^{44}$

The ATJ has also given more deference to national judges than its European counterpart. In a later iteration of the Reynolds Aluminum case, the tribunal considered which of three potentially applicable legal regimes governed the dispute. The ATJ defined the obligations under each regime, one of which gave states complete control over certain products "as long as exception and reserve lists exist." 45 But rather than selecting the relevant rules from among the three options, the ATJ left that key question for national courts to answer. ${ }^{46}$

40. ATJ ruling 2-IP-90, point 1.

41. ATJ ruling 1-INCULP-1987. This early ruling used a the term "INCULP" that was replaced by AI (Acciones de Inculpiementos).

42. Saldias $2007,12$.

43. ATJ ruling 1-IP-90, conclusion point 1.

44. Another example is case ATJ ruling 5-IP-89, in which the ATJ allowed governments to determine whether to prohibit foreign ownership in certain economic sectors.

45. ATJ ruling 3-IP-93, point 2.

46. ATJ ruling 3-IP-93, conclusions point 2: "It is for the [national court] to determine whether the product in question is part of the Free Trade program of the Cartagena agreement, the Nómina de Reserva [which forms part of Andean industrial programs] or the list of exceptions of the member country." 
In striking contrast, the ECJ has a long tradition of reserving to itself the authority to determine the extent of national exceptions to free trade rules. ${ }^{47}$ Moreover, the ECJ directs national judges regarding the application of EC rules. Judge Federico Mancini acknowledged that the ECJ formally refrains from "overstepping" its authority to rule on whether a national law violates European law. But "having clarified the meaning of the relevant Community measure, the court usually indicated the extent to which a certain type of national legislation can be regarded as compatible with that measure. The national judge is thus led hand in hand as far as the door; crossing the threshold is his job, but now a job no harder than child's play." 48 As previously explained, Andean governments had sought to limit the ATJ from similarly guiding the application of national law by initially instructing the tribunal not to consider the facts of referred cases, and later providing that it could only consider the facts "when essential for the requested interpretation." 49

There is thus some textual support for the ATJ's reticence. But the extent of its deference to national governments and judges is surprising. There were a number of ways that the ATJ could have used the aluminum cases to expand the reach and scope of Andean law, and to create a larger role for itself in overseeing Andean legal integration. The ATJ could have found that Andean industrial programs preempted national discretion. It could have declared the exemption list a part of Andean law and itself determined which goods were included on the list. Or it could have allowed national judges to decide individual cases subject to welldefined Andean guidelines for determining the validity of government exemptions. Instead, the ATJ handed to national judges both the task of ascertaining which regime governed and whether a product was included on the list of exceptions, effectively removing itself from determining whether member states were complying with Andean free trade rules.

\section{ATJ Lawmaking During a Period of Relative Political Harmony: 1996-2004}

Would the ATJ become more of an expansionist lawmaker if there were greater political consensus among Andean member states over building a common market? The ATJ faced just such an environment beginning in the mid-1990s. During the earlier Andean Pact period, actors both within and across the member states disagreed vehemently about the import substitution strategy at the center of Andean integration efforts. By the 1990s, the import substitution theory had come into disrepute. Andean governments decisively embraced the neoliberal Washington Con-

47. See Maduro 1998; and Stone Sweet 2004, 122-28.

48. Mancini 1989, 606.

49. See note 20 . 
sensus, adopting sweeping legislative and institutional reforms at the national and regional levels with the renewed goal of building a common market. ${ }^{50}$

In 1993, the Free Trade Zone became fully effective for Bolivia, Colombia, Ecuador, and Venezuela. In 1994, Andean countries agreed to a common external tariff. In 1997, they adopted the Sucre Protocol, which resembled the EC's Single European Act in that it committed member states (including Peru) to finally complete the common market. ${ }^{51}$ Member states also reformed Andean institutions, replacing the ineffectual Andean Junta with a General Secretariat, increasing the size of the Secretariat's budget, and appointing a cadre of young lawyers eager to use those enhanced resources to promote regional integration. ${ }^{52}$

Andean integration still faced challenges, such as Peru's withdrawal from the Common External Tariff and its delay until 2003 in ratifying the Sucre Protocol. But using the Andean legal system to promote compliance with Andean rules was not among them. To the contrary, revisions of the tribunal's jurisdiction in the 1996 Cochabamba Protocol suggested that member states wanted the ATJ to be more assertive in interpreting and enforcing Andean law. ${ }^{53}$

We observe a marked change around this time in ATJ rulings concerning Andean intellectual property law. New Andean secondary legislation (Decisions 311, 313, and 344) expanded the region's intellectual property rules, which led to an increase in applications to register trademarks and patents with national intellectual property agencies. Although detailed, the decisions contained ambiguous provisions and lacunae that the agencies and private litigants sought to clarify in numerous references to the ATJ.

Andean judges responded to these repeated requests by interpreting regional intellectual property rules in ways not dictated by the texts of the Decisions. Some of the tribunal's decisions were relatively modest extensions of established legal principles. For example, the ATJ created judge-made doctrines concerning trademark coexistence agreements and pharmaceutical trademarks that instructed agency officials to balance the private rights of intellectual property owners against the need to prevent consumer confusion and promote public health. ${ }^{54}$

Other decisions were far bolder and substantially cabined national government discretion. The first ATJ noncompliance ruling in 1996, which upheld a General Secretariat challenge to a bilateral agreement between Ecuador and the United

50. See Dezalay and Garth 2002; and Williamson 1990.

51. O'Keefe 1996. For example, the 1997 Sucre Protocol envisioned the phase out of all exceptions to the common market.

52. Interviews by the authors with Monica Rosell, former Legal Secretary of the ATJ and Attorney in the Legal Advisor's Office of the Secretariat General, Quito, Ecuador, 17 March 2005, and Chicago, 1 April 2007. For more, see Helfer and Alter 2009, 881-83.

53. See discussion of changes adopted in Cochabamba Protocol in note 20.

54. For example, ATJ ruling 104-IP-2002 (holding that trademark coexistence agreements do not create an automatic basis for registration, since it is always necessary to place the public interest of consumers over the private interests of the contracting parties); and ATJ ruling 50-IP-2001 (stressing that consumer confusion regarding pharmaceutical products could create irreversible damage to human health). 
States, provides an apt illustration. Adopted under pressure from the U.S. pharmaceutical industry, the bilateral treaty protected drugs in the production "pipeline" before an Andean law recognizing patented medicines took effect. ${ }^{55}$ Ecuador defended the agreement by citing a clause authorizing member states, "in their own domestic legislation or under international treaties, [to] strengthen the intellectual property rights provided for in this Decision." ${ }^{56}$ The ATJ rejected Ecuador's reliance on this seemingly unambiguous text. It reasoned that Andean intellectual property rules were "one of the fundamental pillars for economic harmonization" and "an essential instrument" to "promote well-balanced, harmonious, and equal development" in the region. It then adopted a teleological interpretation of the word "strengthen" that allowed member states to enhance-but not contradictAndean rules and precluded them from invoking bilateral treaties "as a reason to validate noncompliance with a prior Community obligation." 57

In the same year, the ATJ was equally bold in a case referred by the Colombian Constitutional Court concerning the relationship between Andean intellectual property legislation and the Paris Convention - a multilateral patent and trademark treaty. In this ruling, the ATJ addressed the contested issue of national sovereignty. Whereas the ECJ found that EC members had transferred entire domains of sovereign authority to the European level by ratifying the Treaty of Rome, the ATJ reasoned that member states retained control over the pace and scope of the transfer via Andean secondary legislation. The ATJ was unequivocal in stating that sovereignty had in fact been shifted to the Andean Community. But it also reasoned that the more extensive the secondary legislation on point, the more "exclusive authority of the member countries" had been "sovereignly transferred" to the Andean level. Turning to the case before it, the ATJ relied on the existence of extensive and detailed regional intellectual property legislation to rule that significant national authority had been delegated to the community in that domain. The ATJ then asserted its exclusive authority to interpret Andean intellectual property rules and to define their relationship to other intellectual property treaties, making it clear that member states cannot deviate from "the common interests" of the community except by acting together through Andean institutions. ${ }^{58}$

The ATJ extended this approach again in a 2001 decision involving second use patents, another intellectual property right sought by foreign pharmaceutical companies. ${ }^{59}$ The plaintiff argued that the WTO's Agreement on Trade-Related Aspects of Intellectual Property Rights (TRIPS) required second-use patents. Adopting a position arguably bolder than analogous European rulings, the ATJ concluded that Andean law is supreme even over multilateral treaties such as those adopted in the WTO. ${ }^{60}$

55. ATJ ruling 1-AI-96.

56. Article 143 of Andean Decision 344.

57. ATJ ruling 1-AI-96, sections X, XI, and XII.

58. ATJ ruling 1-IP-96, section III.

59. ATJ ruling 1-AI-2001.

60. Ibid., section 7.6. For a review of ECJ rulings regarding WTO law, see Peers 2001. 
In litigation unrelated to intellectual property issues, by contrast, the shift in ATJ decision making was less pronounced. The court became more scrupulous in finding violations of clear Andean rules, in enforcing Andean procedures, and in reviewing the facts of preliminary references. ${ }^{61}$ But it did not issue expansionist rulings that limited state discretion or pushed member states toward deeper levels of legal integration.

The Colombian alcohol monopoly cases illustrate the ATJ's approach during this period. In May 1991, Ecuador complained to the Andean Junta, arguing that municipal rules in Colombia impeded competition and discriminated against Ecuadorian alcohol products. The Junta settled the dispute out of court, but it reappeared in 1996 in a complaint by Venezuela. This time the Junta adopted Resolución 453, a legally binding decision that found fault with Colombian municipalities, and that required Colombia to fix the problem. ${ }^{62}$ When Colombia ignored the resolution, the General Secretariat (which by then had replaced the Junta) filed a noncompliance suit with the ATJ. ${ }^{63}$

Meanwhile, in 1997, a private citizen had asked the Colombian Constitutional Court to review the state's alcohol monopoly. One of the plaintiff's arguments was that the monopoly was incompatible with the Cartagena Agreement as applied in Resolución 453. In its May 1998 judgment, the Colombian court declined to enforce the resolution. It reasoned that, unlike human rights treaties that have quasiconstitutional status in Colombia, ${ }^{64}$ Andean laws were equivalent to domestic legislation. Because such laws "and the Constitution do not share the same hierarchy, nor are [they] an intermediate legal source between the Constitution and ordinary domestic laws, ... contradictions between a domestic law and Andean community law will not have as a consequence the non-execution of the [domestic] law." The court also noted that Andean Community law has "primacy" over conflicting national law - a concept that the Constitutional Court interpreted to mean that Andean law "displaces but does not abrogate or render non-executable" conflicting national legislation. ${ }^{65}$

The ATJ issued its noncompliance judgment six months later. The situation was remarkably similar to the landmark Costa v. Enel decision, in which the ECJ

61. In ATJ ruling 19-IP-98, for example, the ATJ delved into the facts of the case, going beyond the information provided by the parties and leaving no doubt that Venezuela had violated Andean law. Similarly, in ATJ ruling 103-IP-2000, the ATJ concluded that only the General Secretariat, not national governments, can determine if imports from other member countries create temporary market disruptions that justify the imposition of safeguards.

62. This background is referred to in Resolución 453. General Secretariat resolutions are available on the same web portal as ATJ decisions.

63. The case was referred on 20 October 1997. See ATJ ruling 3-AI-97.

64. The Constitutional Court ruling notes that international human rights agreements ratified by Colombia are part of a "bloque de constitucionalidad" that gives them a status superior to national law. Article 93 of Colombia's 1993 Constitution states: "International treaties and agreements ratified by the Congress that recognize human rights and that prohibit their limitation in states of emergency have priority domestically." Colombian Constitutional Court, Sentencia C-256/98 of 27 May 1998, section 3.1.

65. Ibid. 
asserted the supremacy of EC law. But there was a key difference. Costa v. Enel had been simultaneously referred to the Italian Constitutional Court and the ECJ. The constitutional court ruled first, finding that European law was inapplicable to the case at hand and not supreme over national law. ${ }^{66}$ The ECJ, by contrast, found that European law is supreme and that national courts were obliged to apply it instead of conflicting national law, but that the Italian law at issue did not conflict with EC law. ${ }^{67}$ The ATJ was less politically fortunate in that the case involved a Colombian practice that had been challenged by two member states and condemned by a General Secretariat Resolution. Thus, whereas the ECJ found Italian law compatible with EC law, in the alcohol case, the law and facts were such that the ATJ could not avoid ruling against Colombia.

In the noncompliance decision, the ATJ went out of its way to agree with the Colombian Constitutional Court that there was no inherent conflict between the Colombian alcohol monopoly and Andean law. But the implementation of the monopoly was a different matter. Although the national government had tried to introduce a common system of alcohol taxation, local policies that created barriers to trade persisted. Because of these municipal practices, Colombia remained in violation of Andean law.

The same litigant who had filed the Constitutional Court challenge later asked another Colombian court - the Consejo de Estado- to review the municipal policies. To nullify municipal acts, especially after the Constitutional Court ruling, would have been a radical step. National courts in Europe had taken just such a step when they embraced the supremacy of European law. But as of 1999, no court in the Andean Community had shown much willingness to overturn domestic statutes or doctrines to help enforce Andean law. The Consejo referred the case to the ATJ as required under Andean law. The ATJ reiterated that Colombia was obligated to modify practices that conflicted with Andean law. ${ }^{68}$ Yet the ATJ refused to extend its earlier reliance on the European supremacy doctrine and, as the ECJ had done, instruct national judges to do whatever was necessary to give effect to community law. Instead, the ATJ simply declared (again) what Andean law required without asking national judges to help it to enforce that law. Although the ATJ did not explain its reluctance to follow the ECJ, its ruling is difficult to divorce from the very real concern that national judges might find that they lacked the legal authority or the political will to heed the ATJ's request. ${ }^{69}$

Another case further illustrates the ATJ's unwillingness to expand its authority or the reach of Andean law during this period. In 2003, a former staff attorney of

66. Indeed, initially the Italian Constitutional Court suggested that Italian statutes take precedence over the EEC Treaty. Costa v. Enel. \& Soc. Edisonvolta, Italian Constitutional Court Decision 14 of 7 March 1964, [1964] CMLR 425, [1964] I Il Foro It. 87 I 465.

67. Costa v. Enel, supra note 33 .

68. ATJ ruling 29-IP-98.

69. The Consejo de Estado found against the plaintiff in the case, and Colombia has remained in breach of Andean law. Decision of Nov. 11, 1999, regarding Decreto 244 of 1906. For more on national court reticence, see Helfer and Alter 2009, 900-11. 
the General Secretariat raised a case involving Andean rules regulating the use of pesticides in the hopes of eliciting a ruling that would push Colombia to increase national protections. The ATJ found that regional rules required states to improve the quality of health in rural and agricultural industries, and it described the administrative procedures for registering imported and domestic pesticides set forth in the relevant Andean Decisions. But the tribunal refused to go beyond the letter of those Decisions or to guide national authorities in exercising their discretion so as to achieve the Andean Community's broader health goals. ${ }^{70}$

\section{The ATJ in Times of Crisis: 2005 to the Present}

In the mid-2000s, the Andean Community entered a new period of crisis triggered by political and economic schisms between the member states. Colombia and Peru remained true to market liberalization, but Venezuelan President Hugo Chavez advocated a different approach. The election of Evo Morales and Rafael Correa as the leaders of Bolivia and Ecuador in 2006 created a three-country block against new market-oriented initiatives. Policy disagreements led Venezuela to withdraw from the Andean Community in 2006, taking with it a significant portion of the organization's budget.

This political crisis has sapped community resources, slowing the filing of noncompliance suits by the General Secretariat and curtailing efforts to build political support for Andean law within national judiciaries. ${ }^{71}$ It has not, however, noticeably affected ATJ preliminary rulings. The ATJ continues to issue mostly narrow, technical rulings concerning Andean intellectual property law. But the ATJ has also reaffirmed established precedents, even when doing so required confronting governments. In 2005, for example, a private litigant challenged a Colombian tariff that had previously been rejected by the General Secretariat and condemned by the ATJ in a noncompliance case. Extending its earlier ruling regarding the Paris Convention, the tribunal reasoned that regulating the common external tariff was one of the powers that, like intellectual property, had been transferred to the community level. The relevant Andean law permitted countries to derogate from common rules in cases of emergency. But only the General Secretariat could determine whether such derogations satisfied Andean rules. Since the Secretariat had nullified the Colombian tariff, the national court was required to do so as well. ${ }^{72}$ In 2007, the ATJ asserted the supremacy, direct applicability, and pre-emptive power

70. ATJ ruling 137-IP-2003; and interview by the authors with Marcel Tangerife Torres, former member of the General Secretariat legal divison, 10 September 2007, Bogota, Colombia.

71. In 2003, the Andean Secretariat contracted with the Comisión Andina de Juristas to work with national judiciaries to increase awareness about the Andean legal system. Initial ambitious plans had to be significantly scaled back due to a lack of resources. Phone interview by the authors with Salvador Carrasco, Asesor jurídico Comisión Andina de Juristas, 8 December 2008. For more on the Comisión, see 〈http://www.cajpe.org.pe〉, accessed 22 June 2010; and note 106.

72. ATJ ruling 115-IP-2005, considerations point 1. 
of Andean transportation rules, unequivocally stating "there is only one Andean policy in relation to passengers, equipment and transportation." 73

\section{Comparing Twenty-Five Years of Expansionist Judicial Lawmaking by the ATJ and ECJ}

The above analysis encompasses ATJ lawmaking across the universe of ATJ preliminary rulings and important noncompliance decisions. To summarize our findings: early ATJ rulings mostly emulated key ECJ doctrines, making Andean law directly effective and supreme to national law and pre-empting national governments from enacting conflicting domestic legislation. The ATJ stressed that governments had agreed to these developments, which by all appearances is true. The ATJ also enforced clear Andean laws and required national judges to give priority to those laws, particularly in the area of intellectual property. In these ways, the ATJ generally followed in the ECJ's footsteps as a builder and strong defender of a supranational legal order.

In numerous other ways, however, the ATJ has exhibited far more deference to national authority. It has reiterated that Andean legal commitments are a product of member state consent and has scrupulously respected the discretion that Andean secondary law reserves to national governments. The ATJ has also eschewed opportunities to expand the reach and scope of Andean law. While the ATJ formally treats the Cartagena Agreement as higher-order law, the tribunal readily defers to collective decisions concerning the scope and pace of Andean integration when interpreting the treaty. This approach gives member states broad discretion to revise Andean rules to reflect the waxing and waning of their collective commitment to integration.

In contrast to the ATJ, the ECJ is pervasively expansionist. Stone Sweet has examined ECJ decision making involving three substantive areas of European lawthe environment, sex discrimination, and free movement of goods. He concludes that "through its rulings [the ECJ] has acted—relatively systematically—to reduce the domain of national autonomy, to expand supranational modes of governance to the detriment of intergovernmental modes, and to create the conditions for the gradual Europeanization of national administration and judging." 74

Analyzing ATJ and ECJ lawmaking in discrete historical periods revealed another important difference between the two ICs. Weiler observed that in Europe, legal supranationalism advanced furthest when political steps toward integration were in retreat. ${ }^{75}$ The ATJ also developed its key doctrines during its foundational period, but the tribunal's lawmaking tends to reflect rather than counterbalance political support for integration. 


\section{Explaining the Divergent Supply of Expansionist Lawmaking}

What explains these striking differences in ECJ/ATJ lawmaking? The ECJ and ATJ possessed the same potent combination of wide access rules, self-interested litigants, swelling dockets, and repeat player legal entrepreneurs who sought out cases to promote legal integration. ${ }^{76}$ In other words, both ICs contained the ingredients needed for judicial empowerment. But unlike the ECJ, the ATJ often thwarted litigant efforts to use Andean law to dismantle national policies contrary to their economic interests. The ATJ's refusal to help litigants achieve their goals sets up a vicious circle that inhibits the filing of additional cases that might have expanded community law. It is a striking fact that of the 1,338 ATJ preliminary rulings between 1984 and 2007, only thirty-five involve subjects other than intellectual property. ${ }^{77}$ The abstract and repetitive nature of the ATJ's legal analysis also contributes to a sense among lawyers that preliminary rulings have little practical benefit.

Nature-based theories would seek to explain these differences by looking for judicial design features and political constraints that inhibit judges from issuing expansionist rulings in response to litigant demands. But there are no clear differences between the two regional courts on these scores.

One cannot, for example, explain the ATJ's behavior by the judicial appointment choices of governments. In the Andes, as in Europe, governments nominated supranational judges whom they expected to have some expertise in the legal issues the court would hear. Andean governments submit a ranked list of three nominees, which, like their European counterparts, typically hail from government, academia, the foreign service, and the national judiciary. Other member states choose from this list. None of our interviews suggested that governments seek out nominees with particular judicial philosophies or approaches to their job. ${ }^{78}$

76. Repeat players are litigants who raise multiple suits. Scholars assert that repeat players are advantaged in litigation because of their experience, and that repeat players are prevalent in litigation aimed at influencing policy. On the role of repeat players in European integration, see Mattli and Slaughter 1998, 186-89; and Rawlings 1993. We found repeat players in the Andean context in the aluminum, alcohol, and second-use patent cases discussed above, and in rulings analyzing technical issues of Andean intellectual property and tax law.

77. We summarize in more detail the variations in preliminary ruling references in Helfer and Alter, 2009, 886-900. On how "vicious circles" shut down entrepreneurial litigation strategies, see Alter 2000, 512-15.

78. Governments often nominate political allies, although these allies are not always selected by other states. A former ATJ judge recounted his unusual appointment. The government put him third on the list, hoping that one of the two diplomats placed ahead of him would be selected. It later tried to scuttle his candidacy by failing to communicate that he had been selected. (Interview by the authors with a former ATJ judge, 22 June 2007, Lima, Peru.) We also find examples of ATJ judges with clear pro-integration backgrounds. For example, Gallo Pico Mantilla was a committed integrationist with an extensive background in Ecuadorian politics and the diplomatic corps. For more, see Helfer and Alter 2009,880 . 
Once appointed, ATJ judges appear no more vulnerable to retribution than are ECJ judges. Both courts issue rulings unanimously. In neither context have governments attempted to remove judges from office, although they have elected new judges at the end of their terms. Judges rotate in Europe and in the Andes mostly for professional reasons and because new governments want to exercise their power of appointment. ${ }^{79}$

Nor did we find evidence that the ATJ is institutionally more vulnerable than the ECJ. Both European and Andean judges have been criticized for decisions governments did not like. But member states have only rarely overturned unwanted legal rulings. ${ }^{80}$ The ATJ decreased the likelihood of such outright reversals by interpreting the Cartagena Agreement in light of Andean secondary legislation. By contrast, there have been numerous political challenges to the ECJ and national judiciaries regarding the supremacy of European law. ${ }^{81}$ Yet member states have repeatedly extended both courts' jurisdiction. ${ }^{82}$

We next consider whether distinctive features of the Andean context inhibit ATJ expansionist lawmaking. One might argue that Latin American judges are more reluctant to challenge political authority as compared to those in European countries, where constitutional democracy is more firmly entrenched. Yet it is both too sweeping and ahistorical to say that judges in Europe are independent and expansionist, whereas judges in Latin America are politically penetrated and timid. Few judges in Europe in the 1960s and 1970s engaged in judicial review, let alone expansionist lawmaking. ${ }^{83}$

More recently, across Latin America judges are increasingly confronting political power by expanding national and international law, notwithstanding episodes

79. On ECJ judges, see Kenney 1998. Kenney finds no pattern of appointment politics or any indication that political factors influence the selection of ECJ judges (ibid., 128-30). The average length of service for ECJ judges is 9.25 years, which is longer than for ATJ judges in part because there is no limit on the number of times judges can be reappointed (some ECJ judges were on the court for twenty years), and because the Netherlands and Luxembourg generally let judges stay on the court as long as they choose (ibid., 106). Our survey of ATJ judges is less systematic, but we also discern no clear appointment pattern across countries or time. The longest tenure of an Andean judge to date is seven years (and counting). Andean judges generally complete their six-year term (fifteen completed their full term; five were reappointed). Seven judges served fewer than six years, including three of the original judges who left before the ATJ issued any rulings. See Andean Tribunal of Justice 2004.

80. The ATJ's ruling regarding data protection was reversed (See Helfer, Alter, and Guerzovich 2009, 31-34). The Barber Protocol is widely seen as an attempt to curb the effects of an ECJ ruling. See Garrett, Kelemen, and Schulz 1998, 18-20; and Pollack 2003, 359-65.

81. See Alter 2001, especially 156-57, 171, 193-202; and Rasmussen 1986, 351-60.

82. On ATJ, see note 20. The ECJ's jurisdiction was expanded in 1988 (the creation of the Tribunal of First Instance), 1993 (adding financial sanctions for noncompliance), and again in 2009 in the Lisbon Treaty.

83. Merryman's famous explication of the civil law tradition concerned legal practices in both Europe and Latin America (Merryman and Pérez-Perdomo 2007, 156-59). Constitutional courts brought judicial review to Europe, but in both Europe and Latin America, constitutional courts are new and not present in all countries. For more on the development of judicialized politics in Europe, see Stone Sweet 2000. 
of judicial repression. ${ }^{84}$ In Argentina, Chile, Colombia, and Peru, for example, judges have investigated violations of international human rights law and government and military corruption at the highest levels. ${ }^{85}$ Numerous decisions of the Inter-American Court of Human Rights and the Colombian Constitutional Court demonstrate that neither court avoids expansionist lawmaking or confronting political power in high stakes cases. ${ }^{86}$ This reality only deepens our puzzle.

Some observers may focus on the extent to which member states are stable liberal democracies. ${ }^{87}$ Andean countries score reasonably well on measurements of democracy. ${ }^{88}$ But these countries have also experienced significant economic and political crises. ${ }^{89}$ The ATJ's greater willingness to let member states determine the scope and pace of integration arguably reflects the region's unstable political and economic climate. We should not, however, forget that the ECJ too undertook expansionist lawmaking in the face of waning political support for integration, huge student and labor protests in 1968, and mass labor unrest in the 1970s.

A third potential explanation is the differing levels of intra-community trade in the two regions. Intra-European trade was relatively small at the EC's founding, constituting less than 3 percent of the member states' gross domestic product. ${ }^{90}$ Although perhaps not as economically central to European countries in the 1960s, trade among EC member states has always constituted a larger proportion of the total trade as compared to intra-regional trade in the Andes. In 1958, between 23.7 and 27.5 percent of French, Italian, and German trade went to other European member states. By 1972, intra-European trade constituted between 40 and 60 percent of total member states' trade. ${ }^{91}$ Trade among Andean countries increased over the period we study, beginning from a low of 3 percent of total trade during the Andean Pact, peaking at about 10 percent of total trade in 2002. For Bolivia and Ecuador, common market trade is relatively more important (between 15 and 24

84. Hugo Chavez has stacked the Venezuelan judiciary with appointees; Ecuadorian President Lucio Gutiérrez in 2004 sacked his entire Supreme Court, which he claimed was loyal to the opposition; while the Peruvian government pursued Sendero Luminoso (Shining Path) terrorist group, judges often faced death threats; in 1985 the Colombian Palace of Justice was attacked and twelve judges were murdered.

85. See Dargent 2009; Helmke 2005; Sieder, Schjolden, and Angell 2005; Sikkink and Lutz 2001; and Wilson 2009.

86. See Cavallaro and Brewer 2008; and Uprimny 2003.

87. Moravcsik 1997.

88. POLITY scores rate the level of democracy around the world. Out of a possible 10, Andean countries often scored 9, and mostly remained between 7 and 9 during the period of time we studied. Peru plunged to -3 in 1992, and remained at 1 until 2000 when it returned to a 9 rating. European countries mostly scored a 10 during the period of time we study, though France had a score of 5 from 1958 to 1968 , rising to 8 from 1969-85, after which it has remained at a score of 9 .

89. Boltho 1982.

90. Stone Sweet 2004, 57.

91. Figures compiled by the authors from IMF Direction of Trade Statistics, accessed through the Inter-University Consortium for Political and Social Research (ICPSR), available at $\langle$ http://www. icpsr.umich.edu/icpsrweb/ICPSR/studies/7628? archive $=$ ICPSR\&q $=$ direction + of + trade $\rangle$, accessed 22 June 2010. 
percent). ${ }^{92}$ Nevertheless, internal trade has never been as significant in the Andean region as in Europe.

What conclusions can be drawn from these differences? Stone Sweet and Brunnell built on neofunctionalist theory to suggest that increasing trade flows create a demand by private actors for ECJ litigation, which in turn contributes to judicial lawmaking. ${ }^{93}$ Pitarakis and Tridimas respond that Stone Sweet and Brunnell's data cannot determine if trade drives litigation, or litigation drives trade. ${ }^{94}$ In a later analysis, Stone Sweet observes that in Europe, internal trade levels, secondary legislation, and ECJ preliminary rulings rise in tandem, making it impossible to know if legislation drives litigation and trade, or trade drives legislation and litigation. ${ }^{95}$ Scholars are only beginning to untangle these linkages. Early results involving a far more precise coding of ECJ preliminary rulings suggest that ECJ litigation contributes to greater levels of European trade. ${ }^{96}$ This finding tracks what scholars have found with respect to the WTO, namely that law influences trade levels. ${ }^{97}$

Although we lack precise comparative data, we know that the EC has more secondary legislation to promote the free movement of goods, services, capital, and people as compared to the Andean Community. The existence of secondary legislation clearly affects litigation. For example, there is ECJ litigation involving social security benefits for migrant workers, agricultural policies, and common customs classifications for which there is no Andean legislative analogue and thus no Andean litigation. Andean legislation also sometimes contains loopholes that make it hard for litigants to challenge conflicting national policies. ${ }^{98}$ These differences in secondary legislation influence our dependent variable, since the ATJ is more willing to assert its authority in domains where there are extensive Andean rules. ${ }^{99}$ But is trade the driving factor, or does the extent of secondary legislation determine the volume of trade and thus the extent of expansive lawmaking?

It is likely that economic realities influence the extent to which European and Andean governments invest in building a regional economic community. Nonetheless, we find it implausible that different trade levels explain the divergent law-

92. See Evolucion del Proceso de Integracion 1969-1999, CAN document SG/di 219/Rev.1 at 28 (26 April 2000) (on file with authors); Avery and Cochraine 1973, 183; and Hojman 1981.

93. Stone Sweet and Brunell 1998. Stone Sweet and Brunell do not, however, claim that trade levels explain the ECJ's most audacious expansionist lawmaking of the 1960s and 1970s.

94. Pitarakis and Tridimas 2003.

95. Stone Sweet 2004, 57-63.

96. Gabel and Carrubba 2009.

97. Goldstein, Rivers, and Tomz 2007.

98. For example, the Andean telecommunications policy requires governments to provide access to scarce frequencies. But the requirement is "without prejudice to such national provisions as each Member Country may establish," allowing governments to privilege national carriers owned by politically powerful families. (Decision 462, article 23) These and other loopholes are discussed in Helfer, Alter, and Guerzovich 2009, 36.

99. See the discussion of ATJ ruling 1-IP-96 on page 575. 
making by the two regional courts. It is far from clear, for example, that European governments in the 1960 s and 1970 s saw economic integration as vital to their economies. One could easily argue that European governments saw maintaining national barriers to trade as necessary for the larger project of protecting the embedded liberal compromise of postwar European societies. ${ }^{100}$

We therefore proceed to interrogate the power-seeking assumption of naturebased theories. When we shed this assumption, the ATJ's prudent decision to let member states set the pace of integration seems rather unsurprising. What is surprising is that the ECJ repeatedly chose to be an engine for regional integration even when European governments, by all appearances, had largely abandoned the integration project. Jettisoning the assumption that international judges are power-seeking by nature thus calls into question existing explanations of ECJ lawmaking.

Recent historical scholarship has revised previously settled understandings of early European integration by exploring the role of diplomats, lawyers, and judges who supported the ECJ's legal revolution. This new scholarship explains how pro-integration activists wrested the subject of European law from traditional international law scholars, who believed that legal lacunae should be interpreted to preserve state discretion. ${ }^{101}$ Activists founded scholarly and practitioner associations that united pro-integration advocates and worked to educate the larger legal community about the ECJ's view of European law. Pro-integration lawyers then used their positions as judges and court officials to identify test cases and facilitate preliminary references. Pro-integration activists also regularly met with ECJ judges, European Commission members, and pro-integration government officials at events organized by Euro-law associations. At these meetings, which often focused on key unresolved doctrinal issues, ECJ judges learned how different legal interpretations would be received by academics, judges, and officials in key government ministries, and these actors, in turn, encouraged ECJ judges to be bold. $^{102}$

New historical assessments of key decisions in the ECJ's legal revolution reveal the decisive influence of supportive advocacy movements. For example, with respect to the issue of European law supremacy, the European Commission had identified a safer interpretive route grounded in the traditional rules of public international law. These rules indicated that, because the EC treaty did not directly grant legal rights to individuals, European law should not be given direct effect.

100. Milward 1992 makes such an argument with respect to European integration. Ruggie 1983 argues that the only way to make sense of the postwar trade and monetary system is to understand the embedded liberal compromise according to which European and American governments agreed to subordinate the market to the larger purpose of protecting jobs and social welfare so as to preserve social peace.

101. On the construction of "supranational" instead of "international law," see Davies 2008, chap. 2; and Wilson 2008.

102. Vauchez 2007; Alter 2009, chap. 4. 
The rules further indicated that the only way to make European law supreme to national law was to find a basis for supremacy in national constitutions. This traditional international law approach was unsatisfactory, however, because the constitutions of a few member states did not recognize treaties as trumping national law.

The problem became more acute after the Italian Constitutional Court ruled that European law was not supreme to subsequent national legislation. After the Italian ruling, key actors heatedly debated how the ECJ could find a legal basis for EC law supremacy. ${ }^{103}$ Members of the Commission and judges on the court initially skirted the issue. The ECJ asserted the direct effect of European law in its 1962 Van Gend en Loos ruling, but it did not claim that European law was supreme to conflicting national law. ECJ Advocat General Maurice Lagrange also hesitated to claim a basis for supremacy in the Treaty of Rome, suggesting instead that national constitutional interpretation should evolve to recognize EC law primacy. A 1964 meeting of the German Academic Society for European Law focused intensively on this topic. Representatives of the EC legal secretariat, the ECJ, and the German Ministry of Justice were in attendance. The meeting occurred after the Italian Constitutional Court had rejected the supremacy of European law, after Advocat General Lagrange had delivered his reasoned opinion in the ECJ's famous Costa v. Enel case, but before the ECJ had issued its ruling. At the meeting, Hans Peter Ipsen, a highly regarded pro-integration legal scholar, made an impassioned plea that the ECJ go beyond what Lagrange had suggested and assert that the Treaty of Rome itself implied that European law was supreme to national law. ${ }^{104}$ Issued shortly thereafter, the Costa decision closely tracked Ipsen's argument.

Once the ECJ ruled, members of pro-integration advocacy movements wrote scholarly articles championing the ECJ's far-reaching decision, often shedding their affiliations with the integration project so that it appeared that the authors were writing as a random assortment of individual lawyers and scholars. ${ }^{105}$ These actors also helped to persuade sympathetic national judges to issue path-breaking rulings supporting ECJ jurisprudence.

The ATJ, by contrast, has not received the support of legal advocacy networks or national judiciaries. In our interviews in the region, we looked for Andean analogues of the academics, attorneys, and interest groups who spearheaded European legal integration. We identified a few legal entrepreneurs within the Andean system, but no infrastructure or institutions to connect them to each other or to a larger pro-integration movement. Unlike efforts to promote human rights in Latin America, we found no evidence that the Andean integration project has attracted

103. Rasmussen 2010, 71-72.

104. Ipsen 1964. For more, see Alter 2009, 77-78; and Davies 2008, 61-69.

105. See Alter 2009, chap. 4; Rasmussen 2008, 79; Cohen and Madsen 2007; and Madsen and Vauchez 2005. 
the support of national judges, nongovernmental organizations (NGOs), and government officials. ${ }^{106}$

The ATJ does, however, enjoy strong support of national intellectual property agencies. We explore this puzzle in depth elsewhere. ${ }^{107}$ These agencies were restructured in the early 1990s, as part of a larger reform of the administrative state spurred by the Washington Consensus. ${ }^{108}$ The new intellectual property agencies were staffed with Western-trained lawyers who received the financial and material support of the World Intellectual Property Organization and international and regional financial institutions. Andean administrators built an informal regional network to share information and develop criteria to resolve common legal problems. We document how and why national intellectual property agencies looked to the ATJ to interpret ambiguous provisions of Andean law and to provide support in their conflicts with foreign firms and national governments. The result is a symbiotic relationship in which the ATJ develops detailed procedures to help administrators to resolve disputes between private parties, and the agencies, in turn, influence Andean legal doctrines to reflect their own policy preferences. ${ }^{109}$ Unlike the ECJ, however, the ATJ has not seen its support extend beyond the domain of intellectual property.

\section{Conclusion}

International judicial decision making that clarifies ambiguities and fills gaps in treaties is an inherent part of judging. But expansionist lawmaking by international courts and tribunals, in which judges broaden the reach of international legal rules and their authority at the expense of state discretion, may well be the exception, not the rule. Our comparison of the ATJ and ECJ suggests that such lawmaking requires active nurturing by substate and societal actors, which maybut need not-include government officials.

A few conclusions follow from this analysis. First, our comparison of two identically structured ICs suggests that too much weight has been placed on the design of ICs as an explanation of judicial behavior. To be sure, IC design is a relevant factor. For example, both the ECJ and the ATJ are highly active ICs because private litigants can trigger national court references in litigation involving EC or

106. For a discussion of these actors, see Alter 2009, 82-88. We interviewed an organization that appeared to be a natural interlocutor for the ATJ. The Comisión Andina de Juristas is a twenty-fiveyear-old NGO with a mandate to promote civic participation, democracy, and the rule of law in the Andean region. The Comisión has focused on legal problems created by dictatorships and human rights abuses in the region. It views the Andean integration project as less important to its work and just one among many economic arrangements in the region. Phone interview by the authors with Salvador Herencia Carrasco, Asesor jurídico, Comisión Andina de Juristas, 20 May 2008, and 8 December 2008.

107. Helfer, Alter, and Guerzovich 2009.

108. See Dezalay and Garth 2002; and Williamson 1990.

109. Helfer, Alter, and Guerzovich 2009, 12, 21-30. 
Andean Community legislation. But our study demonstrates that ICs can be active without being activist. We also find no evidence that differences in state sanctioning mechanisms meaningfully predict when IC expansionist lawmaking is more or less likely to occur. ${ }^{110}$

Second, although judicial power seeking and self-interest may be necessary for expansionist lawmaking, they are not sufficient. In reopening the question of whether power-seeking explains the ECJ's behavior and in identifying how advocacy movements shaped ECJ lawmaking, our study echoes the findings of Sikkink, Keck, Simmons, and others who find that advocacy networks help build support for international human rights law. ${ }^{111}$ We add to these accounts that actors within states - national judges and national administrators-also provide ICs with constituencies that encourage judicial lawmaking and promote compliance with expansionist rulings. If this explanation is correct, we should expect ICs to supply expansionist decisions when they anticipate that domestic advocacy networks and compliance constituencies will pressure states to change their treaty-incompatible conduct. The support of these domestic interlocutors facilitates IC lawmaking, while the prospect that states may exit from an IC's jurisdiction provides a counterweight. ${ }^{112}$ The reality that advocacy movements and substate actors can encourage expansionist IC lawmaking may be of concern to sovereigntists and defenders of national executive power. Yet we have also shown that the ATJ hewed closely to the mandate given it by the member states, revealing that IC lawmaking does not necessarily compromise national sovereignty.

Finally, our analysis suggests a starting point for future studies of how environmental and political factors shape IC decision making. We compared the behavior of two identically designed ICs in different regions and the behavior of those courts across time. One could also compare ICs within the same region, such as lawmaking by the ATJ in comparison to the Inter-American Court of Human Rights. We expect IC behavior to be influenced by whether substate actors support the larger objectives of the international law regime in which these courts are embedded, and whether the international rules in question are seen as serving larger social and political purposes in addition to promoting the narrow interests of the lawyers and litigants.

It may be that more ICs will resemble the ATJ than the ECJ in their penchant for expansionist lawmaking. Whether or not we are right in this speculation, the

110. A possible exception may be the provisional way that European states initially recognized the jurisdiction of the European Commission and Court of Human Rights (by declarations for a limited time), leading the European Commission to screen out most individual complaints at the admissibility stage, with the result that cases could not then be appealed to the European Court. See Madsen 2010; and Schermers 1999.

111. For example, see Cavallaro and Brewer 2008; Risse, Ropp, and Sikkink 1999; and Simmons 2009.

112. While exit is rare, it is not unheard of (see Helfer 2005). For example, the United States withdrew from the compulsory jurisdiction of the ICJ, and Trinidad and Tobago withdrew from the jurisdiction of the Inter-American Court of Human Rights (see Helfer 2002). 
essential point is that scholars can gain insights by comparing IC behavior across political contexts, and thus investigating when, why, and to what end ICs become expansionist lawmakers and active enforcers of international rules.

\section{Appendix: Research Note}

Given the paucity of literature on the ATJ, we had to make blind choices when we began our investigation. We focused on ATJ preliminary rulings because those decisions have been the most important venue for expansionist ECJ lawmaking, and because preliminary references from national courts are the largest source of ATJ cases. Our coding revealed that 97 percent of ATJ preliminary rulings concern intellectual property issues. Our coding also revealed significant cross-national variation in reference rates to the ATJ. But our interviews suggest that cross-national variation primarily reflects differences in demand for intellectual property rights. In light of the subject matter, concentration of preliminary references, and the fact that cross-national variation in references is highly affected by variations in intellectual property applications, we do not believe that regression analysis of reference patterns would yield useful insights for our dependant variable. Elsewhere, we discuss the patterns of references in detail. ${ }^{113}$

Unlike in Europe, Andean governments rarely offer observations in preliminary reference cases, and ATJ rulings generally provide scant clues as to how national judges should apply the law to the facts. Instead, preliminary rulings mostly contain abstract interpretations of specific provisions of Andean law. For all of these reasons, one cannot conduct the type of analysis undertaken by Carrubba, Gabel, and Hankla to probe for state influence over judicial decision making in preliminary rulings. ${ }^{114}$ Government and General Secretariat positions are, however, discussed in noncompliance cases.

ATJ decisions are reported and referenced by the Secretariat and ATJ using the case number. The letters connote the type of procedure (for example, IP = interpretaciones prejudiciales, $\mathrm{N}=$ nulidad, $\mathrm{AI}=$ Acciones de Incumpliemiento). The last number (for example, 87) corresponds to the year the case was filed (for example, 1987). Access to ATJ rulings has evolved over time. We found the General Secretariat to be a more reliable source, and we relied on their Web site to access decisions. ${ }^{115}$ The number of cases available for download, however, is slightly fewer than the number of cases reported in the ATJ's statistics. There is also a significant mismatch with the data reported on the Integrated Data Base of Trade Disputes in Latin America and the Caribbean, which has its own metric of what qualifies as a dispute. ${ }^{116}$ At the time of our research, ATJ rulings could be downloaded as Word documents. Anticipating that this system may change, we note section headings rather than the page number of the rulings we discuss in detail. Judges are not entirely consistent in how they use section headings or in whether they number their conclusions, which is why sometimes we refer to letters, and other times to numbers.

113. Helfer and Alter 2009.

114. Carrubba, Gabel, and Hankla 2008.

115. Available at: 〈www.comunidadandina.org/canprocedimientosinternet/procedimientos.aspx , accessed 22 June 2010.

116. Available at $\langle$ http://idatd.eclac.cl/controversias/idex_en.jsp〉. 


\section{References}

Alter, Karen J. 2000. The European Union's Legal System and Domestic Policy: Spillover or Backlash? International Organization 54 (3):489-518.

- 2001. Establishing the Supremacy of European Law: The Making of an International Rule of Law in Europe. Oxford, England: Oxford University Press.

2008. Delegating to International Courts: Self-Binding vs. Other-Binding Delegation. Law and Contemporary Problems 71:37-76.

. 2009. The European Court's Political Power: Selected Essays. Oxford, England: Oxford University Press.

Andean Tribunal of Justice. 2004. Testimonio Comunitario. Quito, Ecuador: Tribunal de Justicia de la Comunidad Andina.

Avery, William P., and James D. Cochraine. 1973. Innovation in Latin American Regionalism: The Andean Common Market. International Organization 27 (2):181-223.

Boltho, Andrea. 1982. The European Economy: Growth and Crisis. Oxford, England: Oxford University Press.

Burley, Anne-Marie, and Walter Mattli. 1993. Europe Before the Court: A Political Theory of Legal Integration. International Organization 47 (1):41-76.

Carrubba, Clifford J., Matthew Gabel, and Charles Hankla. 2008. Judicial Behavior Under Political Constraints: Evidence from the European Court of Justice. American Political Science Review 104 (4):435-52.

Cavallaro, James L., and Stephanie Erin Brewer. 2008. Reevaluating Regional Human Rights Litigation in the Twenty-First Century: The Case of the Inter-American Court. American Journal of International Law 102 (4):768-827.

Cohen, Antonin, and Michael Rask Madsen. 2007. 'Cold War Law:' Legal Entrepreneurs and the Emergence of a European Legal Field (1946-1965). In European Ways of Law: Towards a European Sociology of Law, edited by Volkmar Gessner and David Nelken, 175-200. Oxford, England: Hart.

Dargent, Eduardo. 2009. Determinants of Judicial Independence: Lessons from Three 'Cases' of Constitutional Courts in Peru (1982-2007). Journal of Latin American Studies 41:251-78.

Davies, William. 2008. The Constitutionalisation of the European Community: West Germany between Legal Sovereignty and European Integration, 1949-1974. Ph.D. diss., King's College, University of London, London.

Denning, Lord Alfred Thompson. 1990. The European Court of Justice: Judges or Policy Makers? London: Bruge Group.

Dezalay, Yves, and Bryant G. Garth. 2002. The Internationalization of Palace Wars: Lawyers, Economists, and the Contest to Transform Latin American States. Chicago: University of Chicago Press.

Gabel, Matthew, and Clifford J. Carrubba. 2009. The European Court of Justice as an Engine of Economic Integration: Reconsidering Evidence That the ECJ Has Expanded Economic Exchange in Europe. CELS 2009 4th Annual Conference on Empirical Legal Studies Paper. Available at $/$ http:// papers.ssrn.com/sol3/papers.cfm?abstract_id=1444500 $\rangle$. Accessed 22 June 2010.

García Amador, F. V. 1978. The Andean Legal Order: A New Community Law. Dobbs Ferry, N.Y.: Oceana Publications.

Garrett, Geoffrey, R. Daniel Kelemen, and Heiner Schulz. 1998. The European Court of Justice, National Governments and Legal Integration in the European Union. International Organization 52 (1):149-76.

Ginsburg, Tom. 2005. Bounded Discretion in International Judicial Lawmaking. Virginia Journal of International Law 43 (3):631-73.

Goldstein, Judith H., Douglas Rivers, and Michael Tomz. 2007. Institutions in International Relations: Understanding the Effects of GATT and WTO on World Trade. International Organization 31 (1):37-67.

Hartley, Trevor C. 1996. The European Court, Judicial Objectivity and the Constitution of the European Union. Law Quarterly Review 112:95-109.

1999. Constitutional Problems of the European Union. Oxford, England: Hart. 
Hawkins, Darren G., and Wade Jacoby. 2008. Agent Permeability, Principal Delegation and the European Court of Human Rights. Review of International Organizations 3 (1):1-28.

Hawkins, Darren G., David A. Lake, Daniel L. Nielson, and Michael J. Tierney. 2006. Delegation Under Anarchy: States, International Organizations and Principal-Agent Theory. In Delegation and Agency in International Organizations, edited by Darren G. Hawkins, David A. Lake, Daniel L. Nielson, and Michael J. Tierney, 3-38. Cambridge: Cambridge University Press.

Helfer, Laurence R. 2002. Overlegalizing Human Rights: International Relations Theory and the Commonwealth Caribbean Backlash Against Human Rights Regimes. Columbia Law Review 102 (7):1832-911.

- 2005. Exiting Treaties. Virginia Law Review 91 (7):1579-648.

Helfer, Laurence R., and Karen J. Alter. 2009. The Andean Tribunal of Justice and Its Interlocutors: Understanding the Preliminary Ruling Reference Patterns in the Andean Community. New York University Journal of International Law and Politics 42 (4):871-928.

Helfer, Laurence R., Karen J. Alter, and Maria Florencia Guerzovich. 2009. Islands of Effective International Adjudication: Constructing an Intellectual Property Rule of Law in the Andean Community. American Journal of International Law 103:1-47.

Helfer, Laurence R., and Anne-Marie Slaughter. 1997. Toward a Theory of Effective Supranational Adjudication. Yale Law Journal 107 (2):273-391.

Helmke, Gretchen. 2005. Courts Under Constraint: Judges, Generals, and Presidents in Argentina. Cambridge: Cambridge University Press.

Hoffmann, Stanley. 1966. Obstinate or Obsolete? The Fate of the Nation-State and the Case of Western Europe. Daedalus 95 (3):862-915.

Hojman, David E. 1981. The Andean Pact: Failure of a Model of Integration? Journal of Common Market Studies 20 (2):139-59.

Ipsen, Hans Peter. 1964. Haager Kongreß für Europarecht und Bericht über di Aktuelle. Neue Juristische Wochenschrift (Heft 8):339-43.

Keener, E. Barlow. 1987. The Andean Common Market Court of Justice: Its Purpose, Structure, and Future. Emory Journal of International Dispute Resolution 2 (1):37-72.

Kenney, Sally. 1998. The Members of the Court of Justice of the European Communities. Columbia Journal of European Law 5 (1):101-33.

Keohane, Robert O., Andrew Moravcsik, and Anne-Marie Slaughter. 2000. Legalized Dispute Resolution: Interstate and Transnational. International Organization 54 (3):457-88.

Madsen, Mikael Rask. 2010. Legal Diplomacy: Politics and the Genesis of Postwar European Human Rights. In Human Rights in the Twentieth Century: A Critical History, edited by Stephan Ludwig Hoffmann. Cambridge: Cambridge University Press.

Madsen, Mikael Rask, and Antoine Vauchez. 2005. European Constitutionalism at the Cradle. Law and Lawyers in the Construction of a European Political Order (1920-1960). In Lawyers' Circles: Lawyers and European Legal Integration, edited by Alex Jettinghoff and Harm J. C. Schepel, 15-34. The Hague, Netherlands: Elsevir Reed.

Maduro, Miguel Poiares. 1998. We the Court: The European Court of Justice and the European Economic Constitution: A Critical Reading of Article 30 of the EC Treaty. Oxford, England: Hart.

Mancini, G. Federico. 1989. The Making of a Constitution for Europe. Common Market Law Review 24:595-614.

Mattli, Walter, and Anne-Marie Slaughter. 1998. Revisiting the European Court of Justice. International Organization 52 (1):177-209.

Merryman, John Henry, and Rogelio Pérez-Perdomo. 2007. The Civil Law Tradition: An Introduction to the Legal Systems of Europe and Latin America. 3d ed. Stanford, Calif.: Stanford University Press.

Milward, Alan S. 1992. The European Rescue of the Nation-State. London: Routledge.

Moravcsik, Andrew. 1997. Explaining International Human Rights Regimes: Liberal Theory and Western Europe. European Journal of International Relations 1 (2):157-89.

O'Keefe, Thomas Andrew. 1996. How the Andean Pact Transformed Itself into a Friend of Foreign Enterprise. International Lawyer 30 (4):811-824. 
Peers, Steve. 2001. Fundamental Right or Political Whim? WTO Law and the European Court of Justice. In The EU and the WTO: Legal and Constitutional Issues, edited by Gráinne de Búrca and Joanne Scott, 111-30. Oxford, England: Hart.

Pitarakis, Jean-Yves, and George Tridimas. 2003. Joint Dynamics of Legal and Economic Integration in the European Union. European Journal of Law and Economics 16 (3):357-68.

Pollack, Mark A. 2003. The Engines of European Integration: Delegation, Agency, and Agency Setting in the EU. Oxford, England: Oxford University Press.

Posner, Eric A., and John C. Yoo. 2005. A Theory of International Adjudication. California Law Review $93(1): 1-72$.

Rasmussen, Hjalte. 1986. On Law and Policy in the European Court of Justice. Dordrecht, The Netherlands: Martinus Nijhoff.

Rasmussen, Morton. 2008. The Origins of a Legal Revolution: The Early History of the European Court of Justice. Journal of European History 14 (2):77-98.

- 2010. From Costa v. Enel to the Treaties of Rome: A Brief History of Legal Revolution. In The Past and Future of EU Law: The Classics of EU Law Revisited on the 50th Anniversary of the Rome Treaty, edited by Miguel Poiares Maduro and Loïc Azoulai. Portland: Hart.

Rawlings, Richard. 1993. The Eurolaw Game: Some Deductions from a Saga. Journal of Law and Society 20 (3):309-40.

Risse, Thomas, Stephen C. Ropp, and Kathryn Sikkink. 1999. The Power of Human Rights: International Norms and Domestic Change. Cambridge: Cambridge University Press.

Ruggie, John Gerard. 1983. International Regimes, Transactions and Change: Embedded Liberalism in the Postwar Economic Order. In International Regimes, edited by Stephen D. Krasner, 195-232. Ithaca, N.Y., Cornell University Press.

Saldias, Osvaldo. 2007. Supranational Courts as Engines of Disintegration. Berlin Working Paper on European Integration No. 5. Available at 〈http://www.polsoz.fu-berlin.de/polwiss/forschung/ international/europa/arbeitspapiere/2007-5_Saldias.pdf〉. Accessed 22 June 2010.

Schermers, Henry G. 1999. Acceptance of International Supervision of Human Rights. Leiden Journal of International Law 12 (4):821-31.

Shapiro, Martin. 1981. Courts: A Comparative Political Analysis. Chicago: University of Chicago Press.

Sieder, Rachel, Line Schjolden, and Alan Angell. 2005. The Judicialization of Politics in Latin America. New York: Palgrave Macmillan.

Sikkink, Kathryn, and Ellen Lutz. 2001. The Justice Cascade: The Evolution and Impact of Foreign Human Rights Trials in Latin America. Chicago Journal of International Law 2:1-33.

Simmons, Beth A. 2009. Mobilizing for Human Rights: International Law in Domestic Politics. Cambridge: Cambridge University Press.

Slaughter, Anne-Marie, Alec Stone Sweet, and Joseph Weiler. 1998. The European Courts and National Courts: Doctrine and Jurisprudence. Oxford, England: Hart.

Stein, Eric. 1981. Lawyers, Judges, and the Making of a Transnational Constitution. American Journal of International Law 75 (1):1-27.

Steinberg, Richard H. 2004. Judicial Lawmaking at the WTO: Discursive, Constitutional and Political Constraints. American Journal of International Law 98 (2):247-75.

Stephan, Paul B., III. 2002. Courts, Tribunals, and Legal Unification-the Agency Problem. Chicago Journal of International Law 2002 (3):333-52.

Stone Sweet, Alec. 2000. Governing with Judges. Oxford, England: Oxford University Press. - 2004. The Judicial Construction of Europe. Oxford, England: Oxford University Press.

Stone Sweet, Alec, and Thomas Brunell. 1998. Constructing a Supranational Constitution: Dispute Resolution and Governance in the European Community. American Political Science Review 92 (1):63-80.

Tallberg, Jonas. 2003. European Governance and Supranational Institutions: Making States Comply. London: Routledge.

Tsebelis, George, and Geoffrey Garrett. 2001. The Institutional Foundations of Intergovernmentalism and Supranationalism in the European Union. International Organization 55 (2):357-90. 
Uprimny, Rodrigo. 2003. The Constitutional Court and Control of Presidential Extraordinary Powers in Colombia. Democratization 10 (4):46-69.

Vargas-Hidalgo, Rafael. 1979. The Crisis of the Andean Pact: Lessons for Integration among Developing Countries. Journal of Common Market Studies 17 (3):213-26.

Vaubel, Roland. 2006. Principal-Agent Problems in International Organizations. Review of International Organizations 1 (2):125-38.

Vauchez, Antoine. 2007. Judge-Made Law. Aux Origines du Modèle Politique Communautaire (Retour sur Van Gend en Loos et Costa v. Enel). In Une Europe des Élites? Réflexions sur la Fracture Démocratique de L'union Européenne, edited by O. Costa and P. Magnette, 139-66. Brussels: Presses de l'Université Libre de Bruxelles.

Weiler, Joseph H. H. 1981. The Community System: The Dual Character of Supranationalism. Yearbook of European Law 1:257-306. 1991. The Transformation of Europe. Yale Law Journal 100:2403-83.

Williamson, John. 1990. What Washington Means by Policy Reform. In Latin American Adjustment: How Much Has Happened, edited by John Williamson. Washington, D.C.: Institute for International Economics.

Wilson, Bruce M. 2009. Rights Revolutions in Unlikely Places: Colombia and Costa Rica. Journal of Politics in Latin America 1 (2):59-85.

Wilson, Jérôme. 2008. Jurisconsultes et Conseillers D'état: Aux Origines de L'ordre Juridique Communautaire. Journal of European Integration History 14 (2):35-56. 